\title{
The Eurotiomycete Apinisia graminicola as the causal agent of a leaf spot disease on the energy crop Miscanthus $x$ giganteus in Northern Germany
}

\author{
Christian Falter • Christian A. Voigt
}

Accepted: 6 April 2017 / Published online: 14 April 2017

(C) The Author(s) 2017. This article is an open access publication

\begin{abstract}
Miscanthus x giganteus is a fast growing, perennial energy crop for temperate climates. Because of its high annual biomass production rates and its characteristics as a low-input crop, an expansion of field cultivation can be anticipated to cover increasing demands for sustainable biomass production. However, knowledge about pathogens that could have an impact on biomass production is still limited for M. giganteus. Here, we report about the isolation of the filamentous fungus Apinisia graminicola from necrotic leaf lesions of $M$. giganteus grown on a field trial plot in Northern Germany. Inoculation assays with the isolated A. graminicola strain confirmed its capacity to cause a leaf spot disease on M. giganteus. Additional inoculation assays revealed that
\end{abstract}

Electronic supplementary material The online version of this article (doi:10.1007/s10658-017-1226-5) contains supplementary material, which is available to authorized users.

\section{Falter $\cdot$ C. A. Voigt}

Phytopathology and Biochemistry, Biocenter Klein Flottbek, University of Hamburg, Ohnhorststr. 18, 22609 Hamburg,

Germany

C. Falter

Plant Biochemistry and Infection Biology, Biocenter Klein Flottbek, University of Hamburg, Ohnhorststr. 18,

22609 Hamburg, Germany

C. A. Voigt $(\bowtie)$

P3 Institute for Translational Plant and Soil Biology, Department of Animal and Plant Sciences, The University of Sheffield,

Western Bank, S10 2TN, Sheffield, UK

e-mail: c.a.voigt@sheffield.ac.uk
A. graminicola also caused necrotic lesions on leaves of the model grass Brachypodium distachyon. Generally, symptoms of A. graminicola-caused leaf spot disease were stronger on $B$. distachyon compared to $M$. giganteus. Incubation temperatures above $22{ }^{\circ} \mathrm{C}$ during $A$. graminicola infection resulted in stronger disease symptoms on both, $M$. giganteus and $B$. distachyon leaves. Microscopic analysis of cross sectioned, infected leaf tissue revealed an epiphytic mycelium formation on the surface and an endophytic colonization of the mesophyll leave tissue, especially in $M$. giganteus. Our results revealed that the isolated $A$. graminicola strain is a causal agent of a leaf spot disease on grass leaves. Its potential on endophytic growth in M. giganteus might open new possibilities in studying this type of plant-fungal interaction on a cellular and molecular level in an energy crop.

Keywords Miscanthus · Brachypodium - Plant disease · Leaf infection · Endophyte

\section{Introduction}

To supply the increasing demand for energy and natural products deriving from renewable resources, the production of biomass has to be extended because the utilization of agricultural and forestry waste would not produce sufficient biomass if considered as sole lignocellulosic feedstocks. Therefore, cultivating energy crops can be considered as an alternative approach (Somerville et al. 2010), especially to fulfill requirements on sustainable agricultural production systems. These 
would include a high biomass production, low level fertilization, low water consumption, and not being invasive (Dale et al. 2011). Adapted to temperate climates, the fast growing $\mathrm{C}_{4}$ perennial grass Miscanthus $\mathrm{x}$ giganteus would fulfill most of these criteria (Lewandowski et al. 2000; van der Weijde et al. 2013). In addition, $M$. giganteus is one of the most productive energy crops in temperate climate zones (Dohleman and Long 2009; Heaton et al. 2008; Hulle et al. 2012). Its perennial nature is associated with an extended and permanent root system, the so-called rhizome, which can reduce soil erosion and store atmospheric $\mathrm{CO}_{2}$ (Hughes et al. 2010). Its favorable agronomic traits describe $M$. giganteus as a low-input energy crop (Lewandowski et al. 2003). Several studies have revealed the potential of $M$. giganteus biomass production in temperate climates (Lovett et al. 2009; Mishra et al. 2013; Schorling et al. 2015; Stampfl et al. 2007; Thomas et al. 2013). Hence, an expansion of M. giganteus cultivation can be anticipated. Despite its potential for extended sustainable biomass production, the knowledge about emerging pathogens that can infect $M$. giganteus is still limited. Mainly two reasons support the importance of identifying $M$. giganteus pathogens: on the one hand, the possible impact on biomass yield losses due to infection (Stewart, and M. C. 2011); and on the other hand, to host pathogens of other crops (Glynn et al. 2015).

The growing interest in $M$. giganteus cultivation has promoted studies on identifying pathogens of this energy crop where fungal species represent the majority. Pusz and Plaskowska (2010) identified Stagonospora tainanensis as a $M$. giganteus leaf pathogen, which could reduce biomass yields; and Pithomyces chartarum is the causal agent of $M$. giganteus leaf blight with a biomass-reducing potential that might exceed that of S. tainenesis (Ahonsi et al. 2010; Ahonsi et al. 2013). In our recent study (Falter and Voigt 2014), we were able to show the biomass-reducing potential of Bipolaris sorokiniana, Cochliobolus heterotrophus, Stagonospora macropycnidia, and Stagonospora nodorum, which we identified as $M$. giganteus leaf pathogens and which have been well described pathogens of crops (Bakonyi et al. 1998; Oliver et al. 2012; Ullstrup 1972). The list of fungal species was recently extended by the study of Glynn et al. (2015), who identified Rhizoctonia solani, Fusarium poae, Fusarium culmorum, and Sordaria fimicola as putative, emerging $M$. giganteus leaf pathogens.
Our study was aimed at identifying and isolating fungal species from field-grown M. giganteus leaves that revealed necrotic lesions due to infection. We wanted to focus on those fungal species that have not been reported as M. giganteus pathogens before. The inclusion of Brachypodium distachyon as an additional host for newly identified and isolated fungal species from $M$.giganteus leaves would give a first idea about host specificity. Moreover, based on its characteristics as a model plant, $B$. distachyon would facilitate the establishment of model pathosystems with newly identified fungal species, which would provide relatively easy genetic access for molecular studies on the host side (Alves et al. 2009; Draper et al. 2001; International Brachypodium, I 2010). From necrotic leaf lesions of $M$. giganteus, we isolated the ascomycete Apinisia graminicola, a fungus that was first reported as a saprophyte on grass cuttings (La Touche 1968) and has not been described as a plant pathogen yet. The genus Apinisia is a member of the Onygenacea, which is one out of four families within the order of Onygenales (Currah 1985; Kirk et al. 2008). Because many Onygenales reveal a keratinolytic, cellulolytic or chitinoclastic ability, these enzymatic capabilities have been suggested for phylogenetic characterization of Onygenales together with molecular analyses (Currah 1985; Scott et al. 1993; Sugiyama et al. 2002). In addition, morphological features are used to separate families within the Onygenales and genera within a family. Genera assigned to the family of Onygenaceae can be separated based on ascomata configuration, peridium morphology, conidia position and size, or ascospore shape (Currah 1985). In this regard, a globose ascospore shape is characteristic for the genus Apinisia as shown for A. graminicola (La Touche 1968; Sigler et al. 1998). Because of divergent ascospore shape and substrate specificity, A. queenslandica, considered to represent a second species of the genus Apinisia (Apinis and Rees 1976), has been suggested to be redisposed in the genus Uncinocarpus (Sigler et al. 1998). Hence, A. graminicola remains the only undisputed species of the genus Apinisia.

\section{Materials and methods}

Isolation and cultivation of fungal material from M. giganteus leaves

M. giganteus leaves with spot-like necrotic lesions were harvested from a small-scale field trial plot in Wedel, 


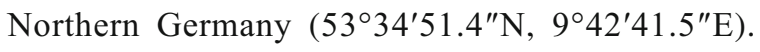
Single necrotic lesions were cut out from leaves, surface sterilized with $70 \%$ ethanol, and transferred on plates containing $\mathrm{CzV} 8 \mathrm{CS}$ medium (modified after Solomon et al. (2004): 33,6 $\mathrm{g} \mathrm{l}^{-1}$ Czapek Dox liquid medium (Oxoid), $3.0 \mathrm{~g} \mathrm{l}^{-1} \mathrm{CaCO}_{3}, 200 \mathrm{ml} \mathrm{l}^{-1}$ Campbell's V8 juice, $20.0 \mathrm{~g} \mathrm{l}^{-1}$ casamino acids, $20 \mathrm{~g} \mathrm{l}^{-1}$ peptone, $20 \mathrm{~g}$ $\mathrm{l}^{-1}$ yeast extract, $3 \mathrm{~g} \mathrm{l}^{-1}$ adenine, $0.02 \mathrm{~g} \mathrm{l}^{-1}$ biotin, $0.02 \mathrm{~g}$ $1^{-1}$ nicotinic acid, $0.02 \mathrm{~g} \mathrm{l}^{-1}$ thiamine, $15 \mathrm{~g} \mathrm{l}^{-1}$ agar agar). Cultivation of plates with necrotic $M$. giganteus leaf tissue was performed at $18{ }^{\circ} \mathrm{C}$ under near-UV light and white light (TL-D $36 \mathrm{~W} / 08$, TL-D $36 \mathrm{~W} /$ 840 , Philips, Netherlands) in a 12-h photoperiod until occurrence of fungal growth out of the tissue. To obtain pure fungal cultures, growing fungal hyphae were separated and cultivated on new $\mathrm{CzV} 8 \mathrm{CS}$ plates. Purity of fungal culture was confirmed by sequencing.

Determination of fungal material from $M$. giganteus leaves

The CTAB protocol was used to isolate genomic DNA of the isolated fungus (Leslie and Summerell 2006). An approximately $900 \mathrm{bp}$ DNA fragment of the 28S ribosomal gene was amplified via PCR by using LROR (5'-ACCC GCTGAACTTAAGC-3') and LR5 (5'-TCCT GAGGGAAACTTCG-3') primers as described by Vilgalys and Hester (1990). For the purification of the PCR product, the NucleoSpin Gel and PCR Clean-up Kit (Macherey-Nagel, Germany) was used according to manufacturer's instruction. To identify the fungal species, the PCR product was sequenced using primers LROR, LR5, LR3R (5'-GTCTTGAAACACGGACC-3') and LR3 (5'CCGTGTTTCAAGACGGG-3') (all primers adapted from Vilgalys and Hester (1990)). The resulting partial sequence of the 28S ribosomal RNA was blasted against the nucleotide collection database at the National Center for Biotechnology Information (NCBI, http://blast.ncbi. nlm.nih.gov/blast.cgi) and stored in GenBank with the Sequence ID: KF647896. The fungal strain isolated from M. giganteus leaves was identified as Apinisia graminicola.

Plant material for leaf inoculation assays

B. distachyon (inbred line $\mathrm{Bd} 21$ (Huo et al. 2006)) was grown in a growth chamber at $22{ }^{\circ} \mathrm{C}$ and a $16 \mathrm{~h}$ photoperiod (HPI-T PLUS $400 \mathrm{~W}$ and SON-T PIA AGRO
400 W, Philips, Netherlands). M. giganteus was grown in a greenhouse with an additional light supply to provide $16 \mathrm{~h}$ light if required.

Droplet inoculation of detached leaves

Detached leaves of 4-5 week old B. distachyon and $M$. giganteus were used in the inoculation assays. Droplet inoculation followed the description in Falter and Voigt (2014). In brief, detached leaves were surface sterilized and transferred on water agar supplemented with kinetin $(1 \mathrm{mg} / \mathrm{ml}) .10 \mu \mathrm{l}$ droplets of gelatine-tween 20 -solution containing mycelium of the newly isolated fungal strain were used for detached leaf inoculations. Incubation of inoculated leaves was performed at $22{ }^{\circ} \mathrm{C}, 26{ }^{\circ} \mathrm{C}$ or $30{ }^{\circ} \mathrm{C}$ in a photoperiod of $16 \mathrm{~h}$ light and $8 \mathrm{~h}$ darkness for 7 days. Control leaves were treated with droplets of the gelatine-tween20-solution.

The relative necrotic leaf area as a scale for disease severity was determined with the ImageJ tools (Rasband,W.S., US National Institutes of Health, Bethesda, Maryland, USA, http://imagej.nih.gov/ij/, 1997-2011) "freehand selection" and "measure" as described in Falter and Voigt (2014).

Statistical analysis

Descriptive statistics including the mean and the standard error of the mean $( \pm \mathrm{SE})$ along with the Tukey range test for multiple comparison procedure in conjunction with an ANOVA were used to determine significant differences. $P<0.05$ was considered significant.

Microscopy of inoculated leaves

The microscopy of inoculated leaves with the confocal laser-scanning microscope LSM 780 (Zeiss, Germany) was performed according to the description in Falter and Voigt (2014) using calcofluor white to visualize fungal mycelium on the leaf surface (Herth and Schnepf 1980), wheat germ agglutinin coupled with the green fluorescent dye CF488A to visualize fungal mycelium inside the infected leaf tissue in cross sections (Mirelman et al. 1975), and aniline blue staining to visualize plant cell walls in cross sections. 


\section{Results}

Identification of a phytopathogenic fungus isolated from $M$. giganteus leaves

We isolated a fungus from M. giganteus leaves showing disease symptoms from a small field trial plot located in Wedel, Northern Germany. Spot-like disease symptoms were restricted to single leaf sections without indication of an epidemic outbreak or severe, large-scale necrosis. For the isolation of putative phytopathogenic fungi from infected tissue, spot-like necrotic lesions were cut out from M. giganteus leaves (Fig. 1a) and placed on $\mathrm{CzV} 8 \mathrm{CS}$ medium. The cultivation of a filamentous fungus growing out of the necrotic leaf tissue was maintained until reaching a pure culture with only one fungal strain. Sequencing of a $28 \mathrm{~S}$ ribosomal RNA gene fragment from the purified fungal strain revealed a $99 \%$ sequence identity to the Ascomycete Apinisia graminicola (La Touche 1968) (Supplementary Data Fig. 1). Cultivation of the isolated A. graminicola strain on nutrition-rich $\mathrm{CzV} 8 \mathrm{CS}$ medium revealed the same morphological characteristic of a dense, white mycelium growth (Fig. 1b) that was previously described for this fungal species (La Touche 1968). Inoculation of intact $M$. giganteus leaves under greenhouse conditions with the isolated A. graminicola induced disease symptoms of spot-like necrotic lesions, which were comparable to those observed on field-grown $M$. giganteus plants (Fig. 1a). We found similar spot-like necrotic lesions also on detached M. giganteus leaves after
A. graminicola inoculation (Fig. 2a) indicating the suitability of the detached leaf assay in surveying infection of this plant pathogenic fungus.

Temperature-dependent disease severity on $B$. distachyon and M. giganteus leaves

Similar to the induction of disease symptoms on detached $M$. giganteus leaves, the isolated A. graminicola strain caused spot-like necrotic lesions on detached B. distachyon leaves (Fig. 2a). Comparing necrotic lesion formation as a scale for disease severity (Falter and Voigt 2014) on both plant species, $B$. distachyon revealed a higher susceptibility to A. graminicola than $M$. giganteus, where only a relatively small leaf area showed necrotic symptoms (Fig. 2). At $22{ }^{\circ} \mathrm{C}$, necrotic lesions covered $2.5 \%$ of the leaf area in B. distachyon and only $1.5 \%$ in $M$. giganteus. In previous studies, global warming has been identified as a potential driver of altered pathogen growth and pathogenicity, and higher temperatures might also impact plant development and defense responses (Chakraborty 2013; Siebold and von Tiedemann 2013). To test possible scenarios of global warming, we also tested disease severity of the isolated A. graminicola strain on $B$. distachyon and $M$. giganteus leaves at $26^{\circ} \mathrm{C}$ and $30^{\circ} \mathrm{C}$. Interestingly, higher incubation temperatures during A. graminicola infection resulted in stronger disease symptoms on both, B. distachyon and M. giganteus leaves (Fig. 2). On M. giganteus leaves, the area of necrotic lesions increased to $3 \%$ at $26{ }^{\circ} \mathrm{C}$ and further rose to $4 \%$ at $30{ }^{\circ} \mathrm{C}$ (Fig. 2b), which was almost three times higher
Fig. 1 Disease symptoms on M. giganteus plants infected with A. graminicola. a Necrotic lesions on $M$.giganteus leaves from which the A. graminicola strain was isolated, scale bar $=1 \mathrm{~cm}$. b Growth morphology of isolated A. graminicola strain on $\mathrm{CzV} 8 \mathrm{CS}$ medium
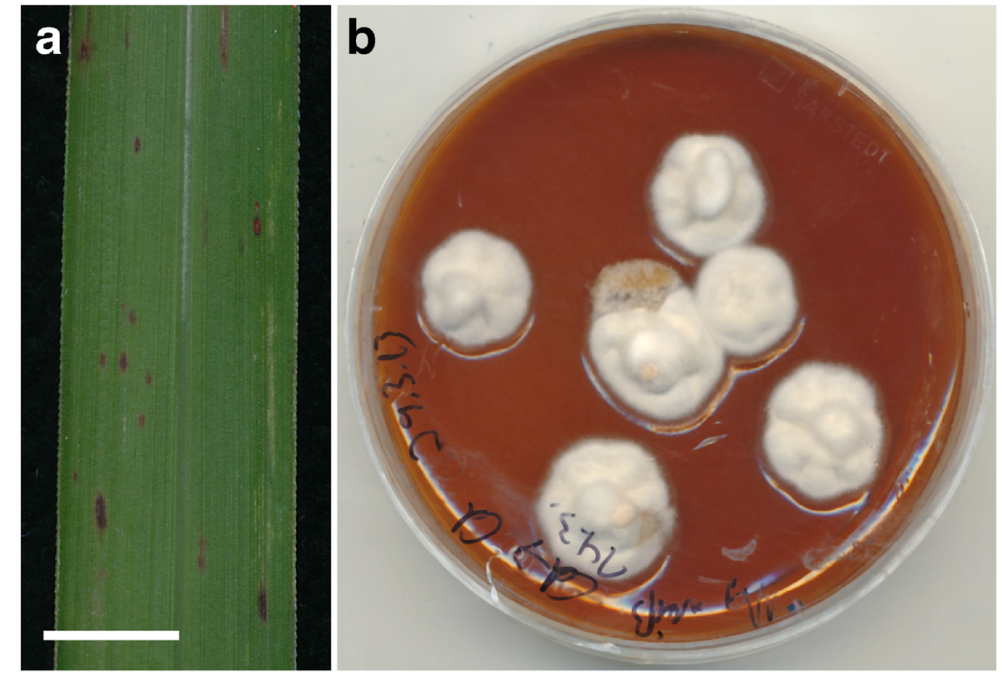
Fig. 2 Temperature-dependent disease phenotypes on

$M$. giganteus and $B$. distachyon leaves caused by A. graminicola. Inoculation of detached leaves was performed with $10 \mu \mathrm{l}$ droplets containing mycelium, control leaves with gelatinetween 20 solution only. Leaves were incubated at $22{ }^{\circ} \mathrm{C}, 26{ }^{\circ} \mathrm{C}$, and $30^{\circ} \mathrm{C}$. a Photos represent disease phenotypes 7 days postinoculation (dpi), scale bar $=1 \mathrm{~cm}$.

b Determination of the relative necrotic leaf area formation $7 \mathrm{dpi}$ as an indicator for disease severity at $22{ }^{\circ} \mathrm{C}, 26^{\circ} \mathrm{C}$, and $30^{\circ} \mathrm{C}$; letters $\mathrm{a}, \mathrm{b}$, and $\mathrm{c}$ indicate groups with $P<0.05$ by Tukey's test, error bars represent SE, and $n=4$
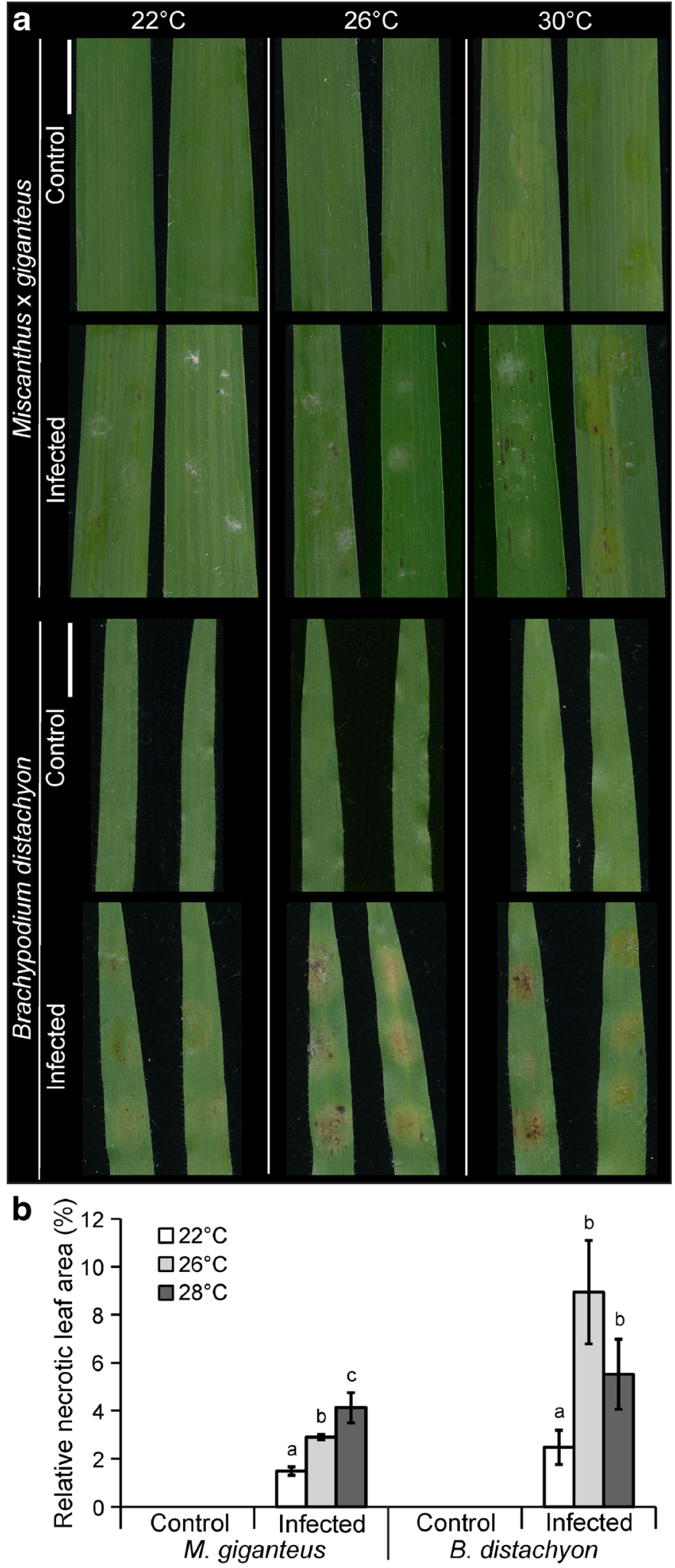
than at $22{ }^{\circ} \mathrm{C}$. On $B$. distachyon leaves, the temperature dependent increase in disease severity of $A$. graminicola was higher compared to $M$. giganteus leaves. Disease symptoms were almost four times stronger at $26^{\circ} \mathrm{C}$ compared to $22{ }^{\circ} \mathrm{C}$; and necrotic lesions covered $9 \%$ of the leaves at the higher temperature (Fig. 2b). This relatively high level of disease severity remained stable at $30{ }^{\circ} \mathrm{C}$ (Fig. 2b).

\section{Cellular analysis of infected B. distachyon} and $M$. giganteus leaves

To examine fungal colonization on leaf surfaces, A. graminicola hyphae were stained with calcofluor white to facilitate high-resolution imaging using a confocal laser-scanning microscope. On both, $M$. giganteus and $B$. distachyon leaf surfaces, $A$. graminicola revealed dense hyphal network formation that exceeded the area of necrotic lesion formation, especially on $M$. giganteus leaves (Figs. 2a and 3), which would be characteristic for epiphytic fungal growth. The occurrence of appressoria-like hyphal structures above developing necrotic lesion formation (Fig. 3) supported the plant pathogenic capacity of the isolated A. graminicola strain. Moreover, aggregation of hyphae occurred in areas of necrotic lesion development, which could have ring-like shapes (Fig. 3). The production of conidiophores on both, M. giganteus and B. distachyon leaves (Fig. 3) showed that A. graminicola was able to complete its life cycle on this leaf tissue. Microscopic analysis of cross sections in the area of necrotic lesion formation confirmed that the isolated A. graminicola strain was able to penetrate and colonize $M$. giganteus and $B$. distachyon leaf tissue. Interestingly, not only epiphytic growth on the leaf surface but also internal hyphal growth exceeded necrotic lesion formation in $M$. giganteus leaf tissue. Lateral hyphal growth underneath the penetration area and outside the area of lesion formation was apoplastic (Fig. 3), which would resemble an endophytic growth capacity. Both, epiphytic and endophytic growth of $A$. graminicola was less pronounced in B. distachyon (Fig. 3).

\section{Discussion}

Combining the relatively limited genetic variety and an expanding cultivation area of $M$. giganteus because of an anticipated increasing demand of sustainable biomass production, this energy crop might be challenged by emerging pathogens. Among pathogens, fungal species would have a high potential to lower biomass yields after infection and successful colonization. In our study, we were able to identify and isolate an A. graminicola strain from field-grown $M$. giganteus that can cause a leaf spot disease. Interestingly, A. graminicola was first described as a saprophyte on decomposing grass cuttings in the UK where the same visible white aggregates of cleistothecia were formed as on V8 juice agar ( $\mathrm{La}$ Touche 1968). Until now, this fungal species has not

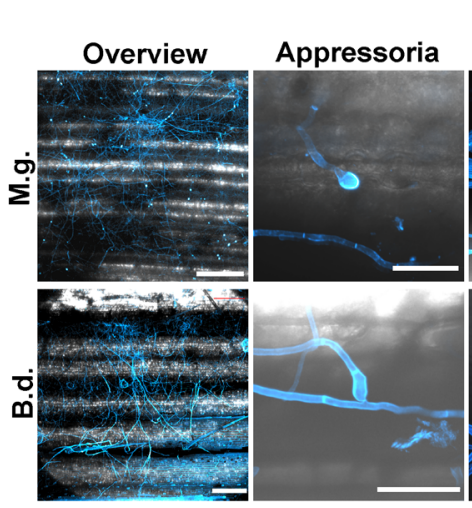

Fig. 3 Microscopic analysis of M. giganteus (M.g.) and $B$. distachyon (B.d.) leaves infected with A. graminicola. Inoculation of detached leaves was performed with $10 \mu \mathrm{l}$ droplets containing mycelium. Micrographs showing superficial hyphal growth, appressoria, and hyphal aggregations were taken 3 days post-inoculation (dpi). Calcofluor white (blue fluorescence) was

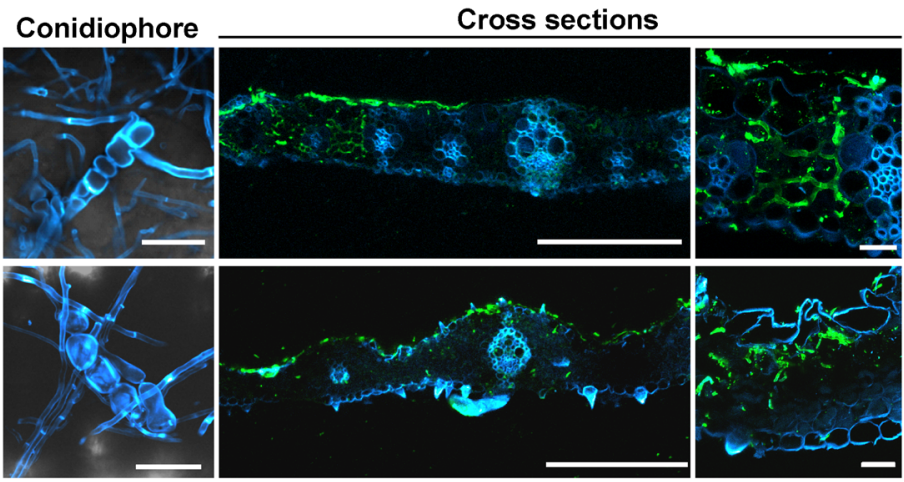

used to stain mycelium. Micrographs from leaf cross sections represent infection progress $7 \mathrm{dpi}$, mycelium was stained with wheat germ agglutinin CF488 conjugate (green fluorescence) and the leaf tissue was visualized with aniline blue (blue fluorescence). Scale bars $=20 \mu \mathrm{m}$ for appressoria and magnified cross sections, scale bars $=100 \mu \mathrm{m}$ for overviews and cross sections 
been reported as a plant pathogen. Because the isolated A. graminicola strain not only infected and colonized $M$. giganteus but also $B$. distachyon leaf tissue, it might not be considered as a forma specialis of $M$. giganteus. A. graminicola belongs the Onygenales (Sugiyama et al. 1999), which is an order of Ascomycota. Recent phylogenetic studies placed A. graminicola in the subcluster of Onygenaceae (Johnston et al. 2015) confirming previous classification of this fungus (Currah 1985; Scott and Untereiner 2004). In this subcluster, A. graminicola showed highest phylogenetic relation to Arachnotheca glomerata, which can be found in soils (Uchiyama and Udagawa 1995). The most related subcluster contained members of keratinophilic fungal species belonging the family of Arthrodermataceae (Johnston et al. 2015), including the pathogenic fungus Microsporum audouinii that can cause mycetoma, a chronic subcutaneous infection of humans (Burton et al. 1980). Even though this might reveal a relative relation to a pathogenic fungus, A. graminicola could not have been anticipated from previous reports of its occurrence or phylogentic analysis to be a causal agent of a leaf spot disease on $M$. giganteus. This is in contrast to already known fungal pathogens of $M$. giganteus with previous reports about infection of other plant species. Pithomyces chartarum, causing leaf blight of M. giganteus (Ahonsi et al. 2010), has also been reported to cause leaf spot of smooth brome (Bromus inermis) (Eken et al. 2006) and leaf blight of wheat (Triticum aestivum) (Tóth et al. 2007); Stagnospora tainanensis, infecting especially young M. giganteus leaves (Pusz and Plaskowska 2010), was previously described as the causal agent of sugarcane (Saccharum officinarum) leaf blight (Hsieh 1979); and several Fusarium species, including F. culmorum and F. graminearum as causal agents of Fusarium head blight in wheat (Osborne and Stein 2007), caused rhizome rot in M. giganteus (Scauflaire et al. 2013). Also in our recent study, where we screened for $M$. giganteus leaf pathogens, all four identified filamentous fungi causing necrotic lesions have previously been reported as pathogens of Poaceae including wheat and maize (Falter and Voigt 2014). A reason why A. graminicola has not been previously identified as a causal agent of a leaf spot disease could be related to its disease severity. On field-grown and greenhouse-grown $M$. giganteus leaves, A. graminearum caused relatively small necrotic lesions. Disease symptoms of a leaf spot disease were similar to those caused by S. tainanensis (Pusz and
Plaskowska 2010), but covered a smaller relative leaf area. Compared to other fungal pathogens with an observed or potential capacity of an epidemic outbreak on $M$. giganteus leaves, associated with biomass reduction, like P. chartarum (Ahonsi et al. 2013) and C. heterostrophus (Falter and Voigt 2014), respectively, we would not expect severe epidemic outbreaks and significant biomass losses caused by A. graminicola infection based on our current knowledge. However, our infection assay data clearly indicated that higher temperature would support severity of $A$. graminicola infection of $M$. giganteus leaves, which we have previously reported also for the plant pathogenic fungi S. nodorum and S. tainanensis (Falter and Voigt 2014). Hence, increasing temperatures due to climate change could support the emergence of new plant diseases caused by fungi that have not been reported as $M$. giganteus pathogens in temperate climates yet.

Our microscopic studies of infected leaf tissue suggest that A. graminicola penetrates directly through the cell wall of epidermal cells. This was supported by the observation that we did not find invasions through stomata. Moreover, A. graminicola hyphae formed appressorialike structures on leaf surfaces in areas of necrotic lesion formation and tissue colonization. The extent to which the observed hyphal aggregations, associated with ringlike shapes, in areas of lesion formation would represent specialized infection structures is not clear. The morphology of A. graminoicola hyphal aggregations differed from so-called infection cushions. These specialized infection structures have been described as a type of compound appressoria. A direct association of these specialized structures with infection was shown for the genii Rhizoctonia, Sclerotinia, and Fusarium (Boenisch and Schäfer 2011; Emmett and Parbery 1975). We also found cushion-like hyphal aggregations on $M$. giganteus and $B$. distachyon leaves infected by B. sorokiniana, $C$. heterostrophus, S. macropycnidia, and S. nodorum in our recent study (Falter and Voigt 2014). In general, formation of appressoria, invasion, and initial fungal colonization of leaf tissue was not different between $M$. giganteus and B. distachyon. Therefore, $B$. distachyon would qualify as a host plant in a model pathosystem to study A. graminicola infection and tissue invasion. In this regard, the model grass $B$. distachyon would have the benefit of a high genetic diversity (Gordon et al. 2014), accessibility to a relatively small, sequenced genome, efficient transformation protocols, and easy cultivation (Alves et al. 2009; Draper et al. 
2001; International Brachypodium, I 2010). However, endophytic growth of $A$. graminicola would not be fully covered by the $B$. distachyon - A. graminicola pathosystem because we observed extended apoplastic growth of A. graminicola in the mesophyll tissue without causing disease symptoms, which is typical for endophytes (Stone et al. 2000), only in M. giganteus leaves. Fungal endophytes can modify plant disease severity (Busby et al. 2016). For example in maize, which is phylogenetically closely related to $M$. giganteus (Lawrence and Walbot 2007), the fungal endophyte Acremonium zeae can support resistance to Aspergillus flavus and Fusarium verticillioides, which are associated with kernel rotting and mycotoxin production (Wicklow et al. 2005). Recently, Chirino-Valle et al. (2016) showed in their study that the application of specific mixtures of Trichoderma species, which are known as fungal root endophytes (Harman 2006), was beneficial for $M$. giganteus biomass production. This effect of Trichoderma species has been associated with an inhibition of plant pathogens through mycoparasitism (Druzhinina et al. 2011), antimicrobial compound production (Reino et al. 2008), and induction of host plant resistance (Harman 2006). In addition, the production of secondary metabolites by Trichoderma species can promote plant growth (Hermosa et al. 2014; Vinale et al. 2008). Therefore, direct application assays with A. graminiocla on M. giganteus could reveal whether this fungus with endophytic growth characteristics would be beneficial for $M$. giganteus growth or provide increased pathogen resistance.

Acknowledgements This work was supported by the German Federal Ministry of Education and Research (grant no. FKZ 0315521A, to C.A.V.).

Open Access This article is distributed under the terms of the Creative Commons Attribution 4.0 International License (http:// creativecommons.org/licenses/by/4.0/), which permits unrestricted use, distribution, and reproduction in any medium, provided you give appropriate credit to the original author(s) and the source, provide a link to the Creative Commons license, and indicate if changes were made.

\section{References}

Ahonsi, M. O., Agindotan, B. O., Williams, D. W., Arundale, R., Gray, M. E., Voigt, T. B., et al. (2010). First report of Pithomyces chartarum causing a leaf blight of Miscanthus $\times$ giganteus in Kentucky. Plant Disease, 94(4), 480-480. doi:10.1094/pdis-94-4-0480c.
Ahonsi, M. O., Ames, K. A., Gray, M. E., \& Bradley, C. A. (2013). Biomass reducing potential and prospective fungicide control of a new leaf blight of Miscanthus $\times$ giganteus caused by Leptosphaerulina chartarum. Bioenergy Research, 6(2), 737-745. doi:10.1007/s12155-012-9293-0.

Alves, S. C., Worland, B., Thole, V., Snape, J. W., Bevan, M. W., \& Vain, P. (2009). A protocol for agrobacterium-mediated transformation of Brachypodium distachyon community standard line Bd21. Nature Protocols, 4(5), 638-649. doi:10.1038/nprot.2009.30.

Apinis, A. E., \& Rees, R. G. (1976). Undescribed keratinophilic fungus from southern Queensland. Transactions of the British Mycological Society, 67, 522-524.

Bakonyi, J., Aponyi, I., \& Fischl, G. (1998) Diseases caused by Bipolaris sorokiniana and Drechslera tritici-repentis in Hungary. In Proceedings of an International Workshop, El Batan, Tex. (Mexico), 9-14 Feb 1997, 1998 1998: CIMMYT/ UCL/BADC.

Boenisch, M. J., \& Schäfer, W. (2011). Fusarium graminearum forms mycotoxin producing infection structures on wheat. BMC Plant Biology, 11(1). doi:10.1186/1471-2229-11-110.

Burton, C., West, M. D., \& Kwon-Chung, K. J. (1980). Mycetoma caused by Microsporum audouinii: First reported case. American Journal of Clinical Pathology, 73(3), 447-454.

Busby, P. E., Ridout, M., \& Newcombe, G. (2016). Fungal endophytes: Modifiers of plant disease. Plant Molecular Biology, 90(6), 645-655. doi:10.1007/s11103-015-0412-0.

Chakraborty, S. (2013). Migrate or evolve: Options for plant pathogens under climate change. Global Change Biology, 19(7), 1985-2000. doi:10.1111/gcb.12205.

Chirino-Valle, I., Kandula, D., Littlejohn, C., Hill, R., Walker, M., Shields, M., et al. (2016). Potential of the beneficial fungus Trichoderma to enhance ecosystem-service provision in the biofuel grass Miscanthus x giganteus in agriculture. Scientific Reports, 6, 25109. doi:10.1038/srep25109.

Currah, R. S. (1985). Taxonomy of the Onygenales: Arthrodermataceae, Gymnoascaceae, Myxotrichaceae and Onygenaceae. Mycotaxon, 24, 1-216.

Dale, V. H., Kline, K. L., Wright, L. L., Perlack, R. D., Downing, M., \& Graham, R. L. (2011). Interactions among bioenergy feedstock choices, landscape dynamics, and land use. Ecological Applications, 21(4), 1039-1054.

Dohleman, F. G., \& Long, S. P. (2009). More productive than maize in the Midwest: How does Miscanthus do it? Plant Physiology, 150(4), 2104-2115. doi:10.1104 /pp.109.139162.

Draper, J., Mur, L. A. J., Jenkins, G., Ghosh-Biswas, G. C., Bablak, P., Hasterok, R., et al. (2001). Brachypodium distachyon. A new model system for functional genomics in grasses. Plant Physiology, 127(4), 1539-1555. doi:10.1104/pp.010196.

Druzhinina, I. S., Seidl-Seiboth, V., Herrera-Estrella, A., Horwitz, B. A., Kenerley, C. M., Monte, E., et al. (2011). Trichoderma: the genomics of opportunistic success. Nature Reviews Microbiology, 9(10):749-759.

Eken, C., Jochum, C. C., \& Yuen, G. Y. (2006). First report of leaf spot of smooth bromegrass caused by Pithomyces chartarum in Nebraska. Plant Disease, 90, 108.

Emmett, R. W., \& Parbery, D. G. (1975). Appressoria. Annual Review of Phytopathology, 13(1), 147-165. doi:10.1146 /annurev.py.13.090175.001051. 
Falter, C., \& Voigt, C. A. (2014). Comparative cellular analysis of pathogenic fungi with a disease incidence in Brachypodium distachyon and Miscanthus x giganteus. Bioenergy Research, 7, 958-973. doi:10.1007/s12155-014-9439-3.

Glynn, E., Brennan, J. M., Walsh, E., Feechan, A., \& McDonnell, K. P. (2015). The potential of Miscanthus to harbour known cereal pathogens. European Journal of Plant Pathology, 141(1), 35-44. doi:10.1007/s10658-014-0519-1.

Gordon, S. P., Priest, H., Des Marais, D. L., Schackwitz, W., Figueroa, M., Martin, J., et al. (2014). Genome diversity in Brachypodium distachyon: Deep sequencing of highly diverse inbred lines. Plant Journal, 79(3), 361-374. doi:10.1111/tpj.12569.

Harman, G. E. (2006). Overview of mechanisms and uses of Trichoderma spp. Phytopathology, 96(2), 190-194. doi:10.1094/Phyto-96-0190.

Heaton, E. A., Dohleman, F. G., \& Long, S. P. (2008). Meeting US biofuel goals with less land: The potential of Miscanthus. Global Change Biology, 14(9), 2000-2014. doi:10.1111 /j.1365-2486.2008.01662.x.

Hermosa, R., Cardoza, R. E., Rubio, M. B., Gutierrez, S., \& Monte, E. (2014). Secondary metabolism and antimicrobial metabolites of Trichoderma. In V. K. Gupta, M. Schnmoll, A. Herrera-Estrella, R. S. Upadhyay, I. Druzhinina, \& M. G. Tuohy (Eds.), Biotechnology and Biology of Trichoderma (pp. 125-137). Waltham, Oxford, Amsterdam: Elsevier.

Herth, W., \& Schnepf, E. (1980). The fluorochrome, calcofluor white, binds oriented to structural polysaccharide fibrils. Protoplasma, 105, 129-133.

Hsieh, W. H. (1979). The causal organism of sugarcane leaf-blight. Mycologia, 71(5), 892-898. doi:10.2307/3759279.

Hughes, J. K., Lloyd, A. J., Huntingford, C., Finch, J. W., \& Harding, R. J. (2010). The impact of extensive planting of Miscanthus as an energy crop on future $\mathrm{CO}_{2}$ atmospheric concentrations. Giobal Change Biology Bioenergy, 2(2), 7988. doi:10.1111/j.1757-1707.2010.01042.x.

Hulle, S. V., Waes, C. V., Vliegher, A. D., Baert, J., \& Muylle, H. 2012. Comparison of dry matter yield of lignocellulosic perennial energy crops in a long-term Belgian field experiment. In Grassland Science in Europe, Volume 17, 2012 2012 (pp. 499-501): Polskie Towarzystwo Łakarskie (polish grassland Society).

Huo, N., Gu, Y. Q., Lazo, G. R., Vogel, J. P., Coleman-Derr, D., Luo, M. C., et al. (2006). Construction and characterization of two BAC libraries from Brachypodium distachyon, a new model for grass genomics. Genome, 49(9), 1099-1108. doi:10.1139/g06-087.

International Brachypodium, I. (2010). Genome sequencing and analysis of the model grass Brachypodium distachyon. Nature, 463(7282), 763-768. doi:10.1038/nature08747.

Johnston, P. R., Nguyen, H. D. T., Park, D., \& Hirooka, Y. (2015). Harorepupu aotearoa (Onygenales) gen. Sp. nov.; a threatened fungus from shells of Powelliphanta and Paryphanta snails (Rhytididae). IMA Fungus, 6, 135-143.

Kirk, P. M., Cannon, P. F., Minter, D. W., \& Stalpers, J. A. (2008). Ainsworth \& Bisby's Dictionary of the fungi (10th ed.). Wallingford, Oxon : CABI.

La Touche, C. J. (1968). Apinisia graminicola gen. et sp.nov. Transactions of the British Mycological Society, 51(2), 283-285. doi:10.1016/s0007-1536(68)80062-2.
Lawrence, C. J., \& Walbot, V. (2007). Translational genomics for bioenergy production from fuelstock grasses: Maize as the model species. Plant Cell, 19(7), 2091-2094. doi:10.1105 tpc.107.053660.

Leslie, J. F., \& Summerell, B. A. (2006). The Fusarium Laboratory Manual. Ames: Blackwell Professional.

Lewandowski, I., Clifton-Brown, J. C., Scurlock, J. M. O., \& Huisman, W. (2000). Miscanthus: European experience with a novel energy crop. Biomass and Bioenergy, 19(4), 209227. doi:10.1016/s0961-9534(00)00032-5.

Lewandowski, I., Scurlock, J. M. O., Lindvall, E., \& Christou, M. (2003). The development and current status of perennial rhizomatous grasses as energy crops in the US and Europe. Biomass and Bioenergy, 25(4), 335-361. doi:10.1016 /S0961-9534(03)00030-8.

Lovett, A. A., Sunnenberg, G. M., Richter, G. M., Dailey, A. G., Riche, A. B., \& Karp, A. (2009). Land use implications of increased biomass production identified by GIS-based suitability and yield mapping for Miscanthus in England. Bioenergy Research, 2(1-2), 17-28. doi:10.1007/s12155008-9030-x.

Mirelman, D., Galun, E., Sharon, N., \& Lotan, R. (1975). Inhibition of fungal growth by wheat germ agglutinin. Nature, 256(5516), 414-416.

Mishra, U., Torn, M. S., \& Fingerman, K. (2013). Miscanthus biomass productivity within US croplands and its potential impact on soil organic carbon. Global Change Biology. Bioenergy, 5(4), 391-399. doi:10.1111/j.17571707.2012.01201.x.

Oliver, R. P., Friesen, T. L., Faris, J. D., \& Solomon, P. S. (2012). Stagonospora nodorum: From pathology to genomics and host resistance. Annual Review of Phytopathology, 50(1), 23-43. doi:10.1146/annurevphyto-081211-173019.

Osborne, L. E., \& Stein, J. M. (2007). Epidemiology of Fusarium head blight on small-grain cereals. International Journal of Food Microbiology, 119(1-2), 103-108. doi:10.1016/j. ijfoodmicro.2007.07.032.

Pusz, W., \& Plaskowska, E. (2010). Stagonospora tainanensis new pathogen of Miscanthus (Miscanthus x giganteus) in Poland. Phytopathologia, 57, 39-43.

Reino, J. L., Guerrero, R. F., Hernández-Galán, R., \& Collado, I. G. (2008). Secondary metabolites from species of the biocontrol agent Trichoderma. Phytochemistry Reviews, 7(1), 89-123

Scauflaire, J., Gourgue, M., Foucart, G., Renard, F., Vandeputte, F., \& Munaut, F. (2013). Fusarium miscanthi and other Fusarium species as causal agents of Miscanthus $\times$ giganteus rhizome rot. European Journal of Plant Pathology, 137(1), 1-3. doi:10.1007/s10658-013-0220-9.

Schorling, M., Enders, C., \& Voigt, C. A. (2015). Assessing the cultivation potential of the energy crop Miscanthus x giganteus for Germany. Global Change Biology. Bioenergy, 7(4), 763-773. doi:10.1111/gcbb.12170.

Scott, J. A., \& Untereiner, W. A. (2004). Determination of keratin degradation by fungi using keratin azure. Medical Mycology, 42(3), 239-246.

Scott, J. A., Malloch, D. W., \& Gloer, J. B. (1993). Polytolypa, an undescribed genus in the Onygenales. Mycologia, 85, 503508. doi: $10.2307 / 3760710$. 
Siebold, M., \& von Tiedemann, A. (2013). Effects of experimental warming on fungal disease progress in oilseed rape. Global Change Biology, 19(6), 1736-1747. doi:10.1111/gcb.12180.

Sigler, L., Flis, A. L., \& Carmicheal, J. W. (1998). The genus Uncinocarpus (Onygenaceae) and its synonym Brunneospora: New concepts, combinations and connections to anamorphs in Chrysosporium, and further evidence of relationship with Coccidioides immitis. Canadian Journal of Botany, 76(9), 1624-1636.

Solomon, P. S., Lee, R. C., Wilson, T. J. G., \& Oliver, R. P. (2004). Pathogenicity of Stagonospora nodorum requires malate synthase. Molecular Microbiology, 53(4), 1065-1073. doi:10.1111/j.1365-2958.2004.04178.x.

Somerville, C., Youngs, H., Taylor, C., Davis, S. C., \& Long, S. P. (2010). Feedstocks for lignocellulosic biofuels. Science, 329(5993), 790-792. doi:10.1126/science.1189268.

Stampfl, P. F., Clifton-Brownw, J. C., \& Jones, M. B. (2007). European-wide GIS-based modelling system for quantifying the feedstock from Miscanthus and the potential contribution to renewable energy targets. Global Change Biology, 13(11), 2283-2295.

Stewart, A., \& Cromey, M. (2011). Identifying disease threats and management practices for bio-energy crops. Current Opinion in Environmental Sustainability, 3, 75-80.

Stone, J. K., Bacon, C. W., \& White Jr., J. F. (2000). An overview of endophytic microbes: Endophytism defined. In C. W. Bacon \& J. F. White Jr. (Eds.), Mirobial endophytes (pp. 329). New York: Marcel Dekker.

Sugiyama, M., Ohara, A., \& Mikawa, T. (1999). Molecular phylogeny of onygenalean fungi based on small subunit ribosomal DNA (SSU rDNA) sequences. Mycoscience, 40, 251258.
Sugiyama, M., Summerbell, R. C., \& Mikawa, T. (2002). Molecular phylogeny of onygenalean fungi based on small subunit (SSU) and large subunity (LSU) ribosomal DNA sequences. Studies in Mycology, 47, 5-23.

Thomas, A., Bond, A., \& Hiscock, K. (2013). A GIS based assessment of bioenergy potential in England within existing energy systems. Biomass and Bioenergy, 55, 107-121. doi:10.1016/j.biombioe.2013.01.010.

Tóth, B., Csosz, M., Dijksterhuis, J., Frisvad, J. C., \& Varga, J. (2007). Pithomyces chartarum as a pathogen of wheat. Journal of Plant Pathology, 89(3), 405-408.

Uchiyama, S., \& Udagawa, S. (1995). Five onygenalean fungi from Japan. Mycoscience, 36, 211-220.

Ullstrup, A. J. (1972). The impacts of the southern corn leaf blight epidemics of 1970-1971. Annual Review of Phytopathology, 10(1), 37-50. doi:10.1146/annurev.py.10.090172.000345.

Vilgalys, R., \& Hester, M. (1990). Rapid genetic identification and mapping of enzymatically amplified ribosomal DNA from several Cryptococcus species. Journal of Bacteriology, 172(8), 4238-4246.

Vinale, F., Sivasithamparam, K., Ghisalberti, E. L., Marra, R., Barbetti, M. J., Li, H., et al. (2008). A novel role for Trichoderma secondary metabolites in the interactions with plants. Physiological and Molecular Plant Pathology, 72(13), 80-86. doi:10.1016/j.pmpp.2008.05.005.

van der Weijde, T., Alvim Kamei, C. L., Torres, A. F., Vermerris, W., Dolstra, O., Visser, R. G., et al. (2013). The potential of C4 grasses for cellulosic biofuel production. Frontiers in Plant Science, 4, 107. doi:10.3389/fpls.2013.00107.

Wicklow, D. T., Roth, S., Deyrup, S. T., \& Gloer, J. B. (2005). A protective endophyte of maize: Acremonium zeae antibiotics inhibitory to Aspergillus flavus and Fusarium verticillioides. Mycological Research, 109, 610-618. doi:10.1017 /S0953756205002820. 